\title{
ADVOCACY ISSUES SURROUNDING EXTERNALLY-FUNDED RESEARCH PROGRAMS
}

\author{
Sidney A. Shapiro, J.D. \\ Rounds Professor of Law, University of Kansas
}

\section{Background, Assumptions, and Introduction}

My teaching and research interests are government regulation, public policy analysis, and lobbying. That is, I teach and study the process by which government reaches decisions, the extent to which those decisions are the products of policy analysis or political power, and how one goes about influencing legislative and executive decision making. I am the author of a law text book on "Regulatory Law and Policy" and I teach a clinic focused on how to be an effective lobbyist. Before I begin teaching, my practice involved public policy analysis and advocacy, and I continue to consult occasionally concerning these areas.

Considering this background, I am particularly interested in one of the topics for discussion in this retreat: "the need to educate the public . . . as to the highly technical substantive and financial realities of today's externally-funded research programs." More specifically, I have the topic of "Advocacy Issues Surrounding Externally-Funded Research Programs."

I will begin with this assumption: A successful research program requires both externally-generated funding and adequate state support of the research infrastructure. In my talk, I will defend the following perceptions:

- $\quad$ Obtaining and maintaining adequate state support requires the use of sophisticated advocacy techniques and skills

- My university and others have failed to employ the advocacy tools that businesses and others employ to obtain their goals. Worse, some of what we now do is positively harmful to our aspirations.

- This failure has several causes, including the fact that typically no top level administrator, with the necessary experience, is in charge of public advocacy. In other words, the responsibility of "managing" a public university includes the responsibility to manage the outside environment. University administration needs to be better at this function.

- $\quad$ The remedy is to adopt the corporate model of advocacy that assigns a vice-president to be in charge of governmental affairs, which helps ensure the coordination of internal management and external advocacy.

\section{The Corporate Model}

My starting point is the corporate model. In his book, Fluctuating Fortunes: The Political Power of Business in America, David Vogel, a professor of business and public policy 
at Berkeley, has written about the history of the corporate model of government affairs. Vogel explains the legislative successes of environmental groups, labor unions, and other progressive forces in the 1960s and early 1970s. This is of interest because conventional political theory predicts that business forces will have greater political influence than others who are not as well organized and financed. Vogel attributes the failure of the business community to stop legislation to the fact that the business community had little or no representation in Washington. In the 1950s, business simply had its way in Washington, without the necessity of having a significant lobbying and public relations presence.

Vogel attributes the political resurgence of the business community in the 1980s to the substantial corporate commitment to all forms of public advocacy. The capstone of such efforts is that almost every American business of any significance has a vice-president in charge of an office of "Government Affairs". This move is important for two reasons. First, it ensures that a top level manager is in charge of the ground troops -- the day-to-day lobbying and public relations efforts. Second, it makes it possible for the corporation to integrate internal management with the way that they handle external public affairs.

\section{The Public Manager}

Philip Heymann of the Harvard Law School and the Kennedy School of Government recognizes these lessons in his book, The Politics of Public Management. The book is for persons who become administrators of government agencies. He argues that such persons conventionally think of management as involving internal management, but management of external relations is even more important in a public organization. He explains:

To a far greater extent in government than in a private corporation, the power to control major management decisions is shared not only with superiors, colleagues, and subordinates, but also with others outside the organization who also have power to share its future and goals. That is called democracy. Each of these outsiders has his own views of what should be done and how. There is no agreedupon bottom line, such as profit or share of the market, to define success. Only in government is an individual's success so often measured by his ability to influence what an organization will regard as its task, not by its success in carrying out a generally accepted set of goals. Similarly, the willingness of crucial outsiders to support the agency will depend as much on their appraisals of its choice of goals as on its execution of them. (Heymann, p. 13)

Heymann's insight rings true for me. Our ability to achieve our internal goals depends heavily on whether those goals also have public support. Equally important, we can do a bangup job of achieving our goals, but unless the public agrees that they are the right goals, we will receive little credit and support for what we do.

This insight is important because of the public skepticism about the functions of government. While any of us in this room can talk for hours about the benefits of public education for our students and our states, the simple fact is that the public and many legislators do not share this viewpoint. 
Heymann's other important insight is that the public manager can influence the public's choice of goals. This is a key thought because it establishes that universities, or any similar public institution, need not be a passive recipient of political fortunes. Heymann then offers a way of modeling or picturing the external environment that suggests what public managers can do to be influential in the legislative process. I would like to turn now to Heymann's model.

\section{The Legislative Process}

As the enclosed chart indicates, Heymann explains the legislative process as consisting of six steps:

- Step 1: What motivates legislators and influences decisions?

- Step 2: What activities influence these motivations?

- Step 3: Does an entity have a comparative advantage in influencing votes as compared to the advantages of its opponents?

- Step 4: What Aresources $\cong$ does an entity have to have to influence votes?

- Step 5: How can the institution develop additional resources?

- Step 6: What is the impact of legislative rules on legislative decisions pertaining to the entity?

This model offers a rich and complex understanding of the legislative process. Today I can only touch on several aspects that are particularly relevant to my topic.

\section{$\underline{\text { Legislative Motivations }}$}

Legislators are influenced by a multiplicity of factors including how a vote will affect the chances of their reelection, and their view of what is public policy. Any vote can implicate all six dimensions, and there can be a tension between the ways in which the six dimensions pull the legislator.

\section{$\underline{\text { Activities }}$}

An organization can engage in several activities that affect the factors that motivate legislators. The state of Kansas had a rare event this year. There was a substantial budget surplus. This was therefore the ideal time to seek additional funding, and the Board of Regents made a halfhearted attempt to do so. Ultimately, this effort was unavailing given the tax-cutting mood of the House of Representatives.

I draw this lesson from our failure. As Heymann teaches, good timing can win votes, but there are other things that must be done as well. The Board of Regents was not ready to put on the type of lobbying campaign that the budget surplus warranted. In particular, higher education lacked a message specifically to counter the tax-cutting sentiment. As indicated, two of Hermann's activities are the design of a legislative initiative and the timing of it.

The University's lobbying efforts are governed by the Board of Regents. But if the 
University had as a senior executive official someone in charge of government affairs, he or she could make it a priority to convince the Regents to be more flexible and timely in setting a lobbying agenda. Moreover, if this person had prior experience in the business world, he or she would be more likely to accomplish this goal. The University could also form a Board of Advisors, which would be composed of corporate lobbyists and others with relevant experience. This would be a resource that could assist the Regents, as well as the University, in setting lobbying priorities.

\section{Comparative Advantages}

The difficulty for universities becomes more obvious when we move to step three and begin to assess the resources that higher education has in influencing the legislative process. The state budget is a limited and shrinking pie, and as compared to other claimants, higher education is lacking in resources merely to maintain, let alone increase, our share of the budget.

\section{Current Resources}

Consider our resources. Only a few legislators are from districts containing universities. Moreover, the leadership of the House of Representatives is extremely hostile to government as a whole, and they are no particular friends of the University. Thus, we lack what Heymann describes as the ability to bargain (bargaining) and the ability to call on leaders in key positions (centrality).

I would argue that, at least at the University of Kansas, we also lack the capacity to persuade. Our lobbyists simply lack a deep understanding of what it is we do. This not because the lobbyists lack skill, but because they are not enmeshed in the day-to-day life of the University in the way that a Vice-Chancellor for government affairs would be. Moreover, the current lobbyists seldom, if ever, call on faculty to explain themselves. Indeed, I believe that they regard faculty as an embarrassment. They are deathly afraid that if a legislator ever met a faculty member, the legislator would never again vote for our appropriation. As a result, legislators gain their impression of the University primarily from knowing our lobbyists, and perhaps an occasional meeting with a University administrator. This is not a setup that is likely to educate legislators about why faculty, and particularly researchers, are important to the state's future.

\section{Future Resources}

Heymann's final notion is that legislative success comes when an entity seeks additional resources to augment the ones it already possesses. An entity can try to put its supporters in key positions of power, but this is an unlikely tactic for universities. However, we can change legislators' attitudes and beliefs, and the beliefs and attitudes of voters.

Let me offer a brief example of how this can be done. The Kansas Trial Lawyers Association (KTLA) has done well with its legislative agenda in the House of Representatives. How can this be? Tort suits and trial lawyers are hardly popular among conservatives, whose main base of financial support is usually the business community. KTLA, however, stressed that 
the entire point of the tort system is "personal responsibility" and that the various roadblocks that prevent plaintiffs from recovering damages deter personal responsibility. This approach recognizes the values of its audience and speaks to what concerns them.

The goal of changing legislative and public attitudes has several implications for universities. First, public relations matters. Second, public relations must be coordinated with a university's legislative objectives and lobbying efforts to be effective. This requires university leaders to choose topics and themes for their speeches and talks, and to constantly reemphasize these themes to educate both the public and its legislators. In politics, saying something once or twice will not work. The same theme or idea must be repeated again and again. I do not perceive that university administration takes this approach to its public education efforts.

Another important point is that universities cannot send mixed messages. Someone has to be in charge of vetting what the University says and does for consistency with its legislative efforts. Allow me an example. The Endowment Association of the University of Kansas just announced that it is purchasing a new plane for the Chancellor and others. The press release explains that because the engines on the existing plane can no longer economically be rebuilt, the Endowment Association found it more cost-effective to purchase a new airplane. So far, so good. But the Endowment Association chose to replace the existing propeller airline with a $\$ 4$ million private jet. I frankly do not know whether the University needs a jet instead of another propeller airplane. What I do know is that this a significant public relations problem.

Faculty and administrators understand that the state should provide the basic infrastructure for the functioning of our universities. Additionally, we know that private funds are given to provide a margin of excellence. Finally, we all know that the University of Kansas, like other universities, is always seeking additional support from the legislature. Our explanation that Awe are lucky to have generous alumni whose directed gifts improve the university's circumstances $\cong$ seems to go unheard by many of those who are divvying up the financial pie. To them, money is money; they reply, AYou can't need money all that badly if you can afford a $\$ 4$

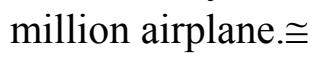

There are ways that the story could have been presented to reduce the damage, but to an outsider, it appears that no one recognized the importance of defending the choice of the more expensive jet plane over the significantly less expensive propeller plane. Better yet, if the University had someone in charge of government affairs, that person might have tried to head off the purchase altogether.

\section{Spinning Is Best Left to President Clinton}

By now, I suspect you may be appalled at the idea that I am urging universities to engage in what politicians call "spinning." As Debra Stone, a political scientist explains, politics is about telling stories. My contention is that it takes a good "story" to compete against the other stories. We did not make the political system and although we would probably like to reform it, it is not going to change any time soon. Thus, the reality remains. Unless we have a good story, we will get left behind. Indeed, we have gotten left behind. 
Spinning has gotten a bad name because it is associated with the idea that any goal or end can be sold if you put the right spin on it. I do not believe this. Unless you have a good story to tell, the public and the legislature will see through what you are trying to do, at least a good percentage of the time.

But we do have a good story to tell. The problem is that we do not know how to tell it. And until we address this problem, I see little hope to escape the creeping mediocrity that is slowly infecting our efforts to do good teaching and research. 